\title{
DIRECT SYNTHESIS AND CHARACTERIZATION OF PHOTO- CROSSLINKABLE BIODEGRADABLE PLA-PEG-PLA TRIBLOCK COPOLYMER WITH METHACRYLATES FUNCTIONS BY GREEN MONTMORILLONITE CLAY CATALYST
}

\author{
Mohamed Benachour ${ }^{1}$, Aslya El-Kebir ${ }^{1}$, Amine Harrane ${ }^{1,2}$, \\ Rachid Meghabar ${ }^{1}$, Mohammed Belbachir ${ }^{1}$
}

https://doi.org/10.23939/chcht14.04.474

\begin{abstract}
Di-methacrylated PLA-PEG-PLA triblock copolymers of polylactide and polyethylene glycol were synthesized in one-step process by bulk cationic polymerization of lactide in the presence of PEG with different average molecular weights, using Maghnite- $\mathrm{H}^{+}$, an acidic montmorillonite clay, as a solid non-toxic catalyst. The obtained di-methacrylated copolymer was analyzed by ${ }^{1} \mathrm{H}$ NMR and DSC. The effect of Maghnite$\mathrm{H}^{+}$proportions and $\mathrm{PEG}$ average molecular weight on the copolymerization and methacrylation yields and on average molecular weight of the resulting copolymers was studied.
\end{abstract}

Keywords: ringopening, polymerization, block copolymers, cationic polymerization, methacrylate copolymers, montmorillonite.

\section{Introduction}

Functional triblock copolymers based on polylactide (PLA) and polyethylene glycol (PEG) have recently attracted great interest due to their biocompatible and biodegradable nature. The synthesis of these amphiphilic block copolymers and their applications in biomedical field such as in drug delivery has been largely described in the literature [1-11]. Recently, bioadsorbable hydrogels have been made from a block copolymer of PLA and PEG, both having biocompatible and biodegradable nature, and were applied to the development of micelle-like nanoparticles as chemotherapeutic carrier [12-17], short interfering RNA delivery system for

\footnotetext{
${ }^{1}$ Laboratoire de Chimie des Polymères, Département de Chimie, FSEA, University of Oran 1 Ahmed Benbella BP N 1524 El M’Naouar, 31000 Oran, Algeria

${ }^{2}$ FSEI University of Abdelhamid Ibn Badis - Mostaganem

amineharrane@yahoo.fr

(c) Benachour M., El-Kebir A., Harrane A., Meghabar R., Belbachir M., 2020
}

heart regeneration [18], vaccine delivery system against hepatitis B $[19,20]$, injectable scaffolds in the tissue engineering [1-3], etc.

The principal method used for the synthesis of dimethacrylated block copolymer PLA-PEG-PLA consists of two steps: the synthesis of di-hydroxyl PLA-PEG-PLA by the polymerization of lactide in the presence of PEG as macro-initiator using organo-metallic catalysts, such as stannous octoate [1, 13, 19-23], and esterification reaction by methacryloyl chloride or methacrylic anhydride to produce di-methacrylated copolymers [23-24]. For biomedical applications, traces of metallic catalysts must be absolutely removed from the polymer because of its toxicity. Therefore, purification of the resulted product requires more rigorous and expensive methods [24-25].

Maghnite- $\mathrm{H}^{+}$is acidified Algerian montmorillonite clay. It exhibits a high cationic exchange capacity $(\mathrm{CEC}=$ $=91 \mathrm{meq} / 100 \mathrm{~g}$ ) [26] and good efficiency for cationic polymerization of vinylic and heterocyclic monomers [2731] and presents the advantage to be non-toxic, ecologic, economic, and regenerable by simple filtration.

In this work, we propose to use Maghnite- $\mathrm{H}^{+}$as nontoxic catalyst for the synthesis of PLA-PEG-PLA dimethacrylated tribolck copolymer. This method permits to obtain the functional copolymer with a good yield and totally free of traces of catalyst by a simple solubilization and filtration method. This copolymer was analyzed by ${ }^{1} \mathrm{H}$ NMR and DSC. The effect of Maghnite- $\mathrm{H}^{+}$proportions and PEG average molecular weight on the copolymerization and methacrylation yields and on the average molecular weight of the resulting copolymers was studied.

\section{Experimental}

\subsection{Materials}

PEG $\left(M_{n}=1000,2000\right.$ and 3000) were purchased from Aldrich Chemical (France). methacryloyl chloride 
(>97\%), dichloromethane and diethyl ether (Sigma Aldrich, France) were used as received. DL-lactide (Sigma Aldrich, France) was purified by recrystallization in ethyl acetate before use.

\subsection{Characterization}

${ }^{1} \mathrm{H}$ NMR and spectra were recorded in (DMSO-6d) on a Bruker spectrometer $300 \mathrm{MHz}$. X-ray diffraction (XRD) of Maghnite was performed on a Brucker D8 Advance. The measures were performed between $0^{\circ}$ and $70^{\circ}$ using a $0.02^{\circ}$ step. Differential scanning calorimetry (DSC) measurements were carried out under nitrogen on a Perkin Elmer Instrument DSC6 thermal analyzer. Samples were submitted to a first heating scan followed by a fast cooling $(20 \mathrm{~K} / \mathrm{min})$ to $208 \mathrm{~K}$ and a second heating scan at $10 \mathrm{~K} / \mathrm{min}$ to $453 \mathrm{~K}$. Glass transition temperature $\left(T_{\mathrm{g}}\right)$ was measured on the second heating ramp.

\subsection{Preparation of Maghnite-H+}

The preparation of the catalyst was made by the treatment of pre-treated Maghnite (procured from ENOF society Maghnia -ALGERIA-) with a solution of $0.25 \mathrm{M}$ sulfuric acid as described by Belbachir et al. [20]. $30 \mathrm{~g}$ of pretreated Maghnite were stirred in $100 \mathrm{ml}$ of distilled water. After $2 \mathrm{~h}, 100 \mathrm{ml}$ of an aqueous solution of $0.5 \mathrm{M}$ sulfuric acid were added and stirred for $48 \mathrm{~h}$. The clay was then filtered, rinsed with distilled water, dried in an oven at $383 \mathrm{~K}$, crushed and stored away from moisture.

\subsection{Synthesis of Di-Metacrylated PLA- PEG -PLA Triblock Copolymer}

The reaction of copolymerization of DL-lactide with PEG was conducted in bulk with Maghnite- $\mathrm{H}^{+}$as catalyst. $1 \mathrm{~g}(6.9 \mathrm{mmol})$ of DL-lactide, $0.69 \mathrm{mmol}$ of PEG, and $0.1 \mathrm{~g}(10 \% \mathrm{w} / \mathrm{w}$ of lactide $)$ of dried Maghnite$\mathrm{H}^{+}$were stirred at $393 \mathrm{~K}$. After $48 \mathrm{~h}$ the product was cooled at room temperature. A solution of $2.8 \mathrm{mmol}$ of methacryloyl chloride in $10 \mathrm{ml}$ of dichloromethane (4 eq. of methacryloyl/polymer chain) was then added dropwise. The reaction was maintained at room temperature for $1 \mathrm{~h}$ and then heated at $353 \mathrm{~K}$ for $3 \mathrm{~h}$. At the end of the reaction, the product was cooled to room temperature and solubilized in $10 \mathrm{ml}$ of dichloromethane. The obtained solution was filtered to remove the catalyst and precipitated in $100 \mathrm{ml}$ of cold diethyl ether. The product was then dried under reduced pressure, weighed and analyzed by ${ }^{1} \mathrm{H}$ NMR and DSC.

\section{Results and Discussion}

\subsection{Characterization of the Catalyst}

The X-ray diffraction spectrum of Maghnite is reported in Fig. 1. The appearance of a series of characteristic peaks confirms that Maghnite is composed essentially by montmorillonite fraction (Table 1). The characterization measurements $[26,30-31]$ show that Maghnite is an aluminosillicate montmorillonite clay with the basic repeating unit of $\left[\mathrm{Si}_{4} \mathrm{O}_{10} \mathrm{Al}^{3+}(2-x) \mathrm{Mg}^{2+} x(\mathrm{OH})_{2}\right]$. It exhibits a cationic exchange capacity (CEC = $91 \mathrm{meq} / 100 \mathrm{~g}$ ) and specific surface area (SSA) of $710 \mathrm{~m}^{2} / \mathrm{g}$.

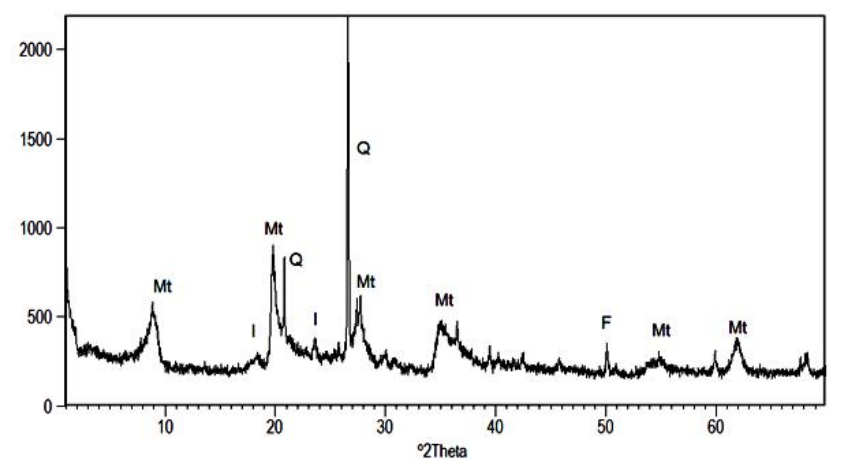

Fig. 1. XRD diffraction of raw Maghnite

Table 1

XRD characteristics of Maghnite

\begin{tabular}{|c|c|c|}
\hline Position $2 \theta \mathrm{Cu} \mathrm{K} \alpha$ & $d_{h k l} \AA$ & Phase identification \\
\hline 6.00 & 14.72 & Montmorillonite (MT) \\
\hline 20.00 & 4.44 & Montmorillonite (MT) \\
\hline 20.90 & 4.25 & Quartz (Q) \\
\hline 26.00 & 3.75 & Quartz (Q) \\
\hline 26.60 & 3.35 & Feldspath (F) \\
\hline 27.35 & 3.21 & Montmorillonite (MT) \\
\hline 35.00 & 2.56 & Montmorillonite (MT) \\
\hline 55.00 & 1.67 & Montmorillonite (MT) \\
\hline 62.00 & 1.50 & \\
\hline
\end{tabular}




\subsection{Synthesis of Di-Methacrylated Poly(lactide-block-ethylene glycol - block-lactide)}

Di-methacrylated PLA-PEG-PLA triblock copolymer was synthesized by cationic polymerization of D,Llactide in the presence of polyethylene glycol as a termination agent, using Maghnite- $\mathrm{H}^{+}$as non-toxic solid catalyst and by adding methacryloyl chloride in the second phase of the reaction (Scheme 1). This alternative method permits to obtain the functional copolymer with a good yield and free of catalyst traces, in this case the solid catalyst was totally removed by a simple filtration after the solubilization of the copolymer in an appropriate solvent [20]. The proof for this copolymerization was obtained by ${ }^{1}$ H NMR and DSC. Chromatograms resulting from gel permeation chromatography (GPC) analysis were monomodal, which confirm the absence of PLA homo-polymers.

${ }^{1} \mathrm{H}$ NMR (Fig. 2) shows peaks at 5.1 and $1.4 \mathrm{ppm}$, corresponding to the PLA methine and methyl groups, and a peak at $3.4 \mathrm{ppm}$, corresponding to the PEG methylene groups. The peak at $4.1 \mathrm{ppm}$ is assigned to the methylene groups in PEG segments next to the - $\mathrm{COO}$ - group of PLA. The presence of methacrylate groups at the end of copolymer chains is confirmed by the two peaks at 6.1 and $5.7 \mathrm{ppm}$ assigned to the vinylic protons. This spectrum is in good agreement with those corresponding to difunctional methacrylated PLA-PEG-PLA triblock copolymer published in the literature [1, 24-25]. The number-average molecular weight of the PLA block was estimated from the integrations of the peaks at $3.4 \mathrm{ppm}$ $\left(I_{3,4}\right)$ and $5.1 \mathrm{ppm}\left(I_{5,1}\right)$ and average molecular weight of used PEG as described in a previous work. The methacrylation yield was also determined by comparing the integrations peak of vinyl protons (6.1 and $5.7 \mathrm{ppm})$ with non-methacrylated PLA chain ends at $4.3 \mathrm{ppm}$.

\subsection{Thermal Properties}

Thermal properties of the resulted di-methacrylated PLA- PEG -PLA copolymer are studied by differential scanning calorimetry (DSC). The results are shown in Fig. 3. Glass transition temperature $T_{g}$ of the material was observed at $235 \mathrm{~K}$. During the heating process, one crystallization peak appears at $T_{c}=267.12 \mathrm{~K}$ and also one melting peak is observed at $T_{m}=310.82 \mathrm{~K}$. These results are in good agreement with those reported in the literature for functional PLA- PEG -PLA copolymers [24, 31-33]. The presence of one value of $T_{g}$, different from those of the two homopolymers PLA and PEG confirms that only PLA-PEG-PLA was obtained and not a mixture of PLA and PEG homopolymers [32, 35].
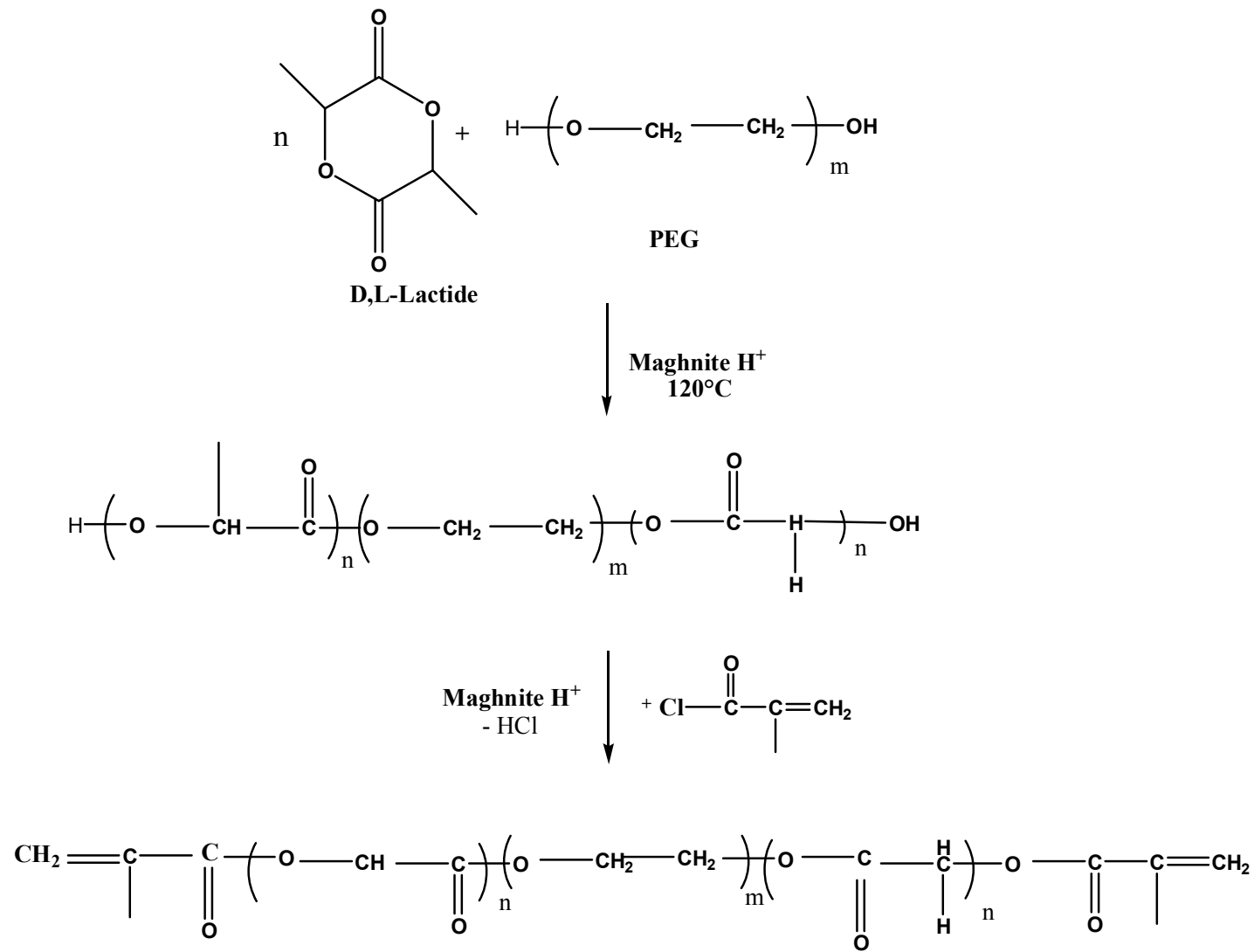

Scheme 1. Di-methacrylated PLA-PEG-PLA synthesis by Maghnite- $\mathrm{H}^{+}$ 


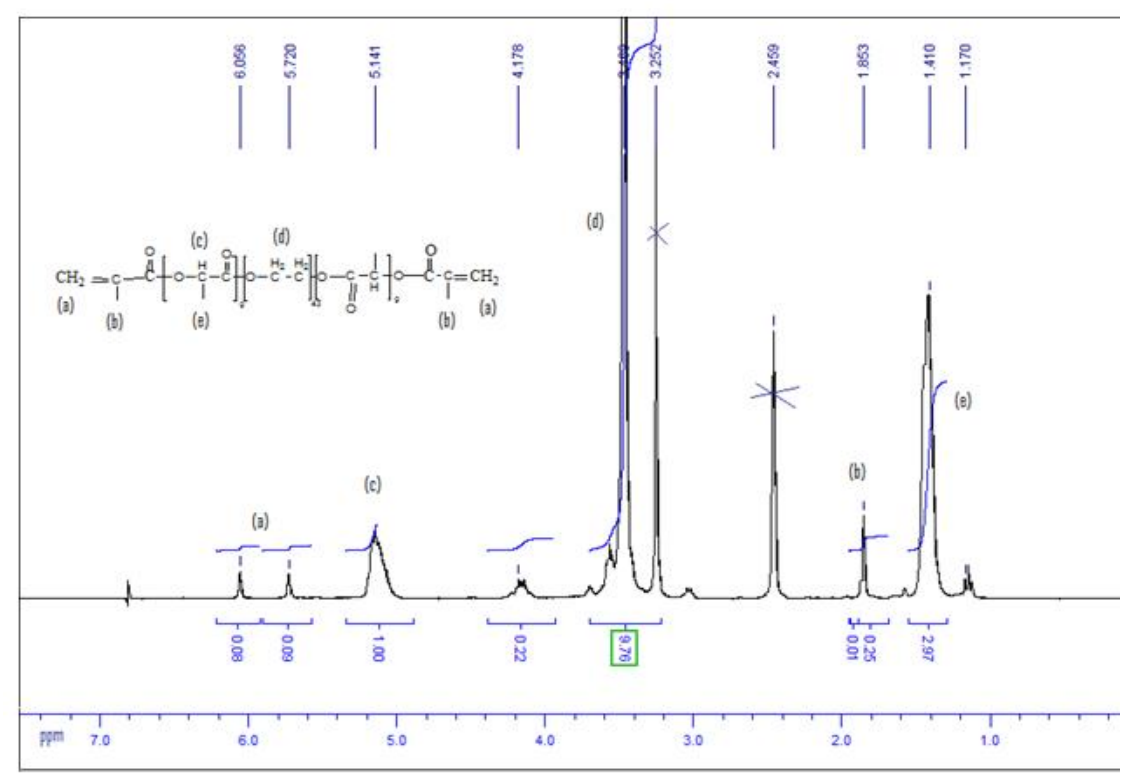

Fig. 2. ${ }^{1} \mathrm{H}$ NMR of the resulted diacrylated PLA-PEG-PLA by Maghnite- $\mathrm{H}^{+}$( solvent DMSO 6d)

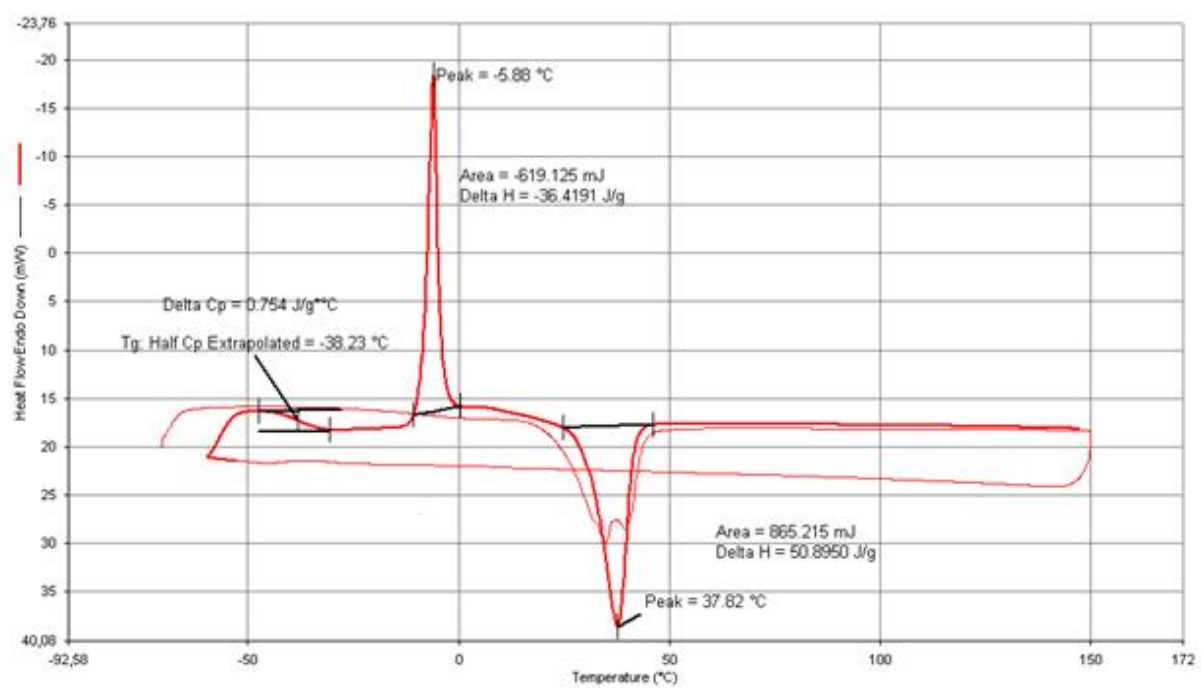

Fig. 3. DSC thermogram of the resulted di-methacrylated PLA-PEG-PLA

\subsection{Kinetics of the Reaction}

\subsubsection{Effect of Maghnite- $\mathrm{H}^{+}$amount}

The effect of the catalyst amount is shown in Figs. 4, 5 and Table 2. The results show that the copolymerization yield increases with the amount of Maghnite- $\mathrm{H}^{+}$. The effect of Maghnite- $\mathrm{H}^{+}$as a cationic catalyst for polymerization of lactide is clearly shown. Fig. 5 shows the effect of catalyst amount on the average molecular weight of the resulting copolymer. The curve shows a decrease of the molecular weight of the PLA block with increasing amount of the catalyst. This is explained by the increase of the number of active sites with catalyst amount, which promote the initiation step to the propagation detriment and cause higher reaction yields but also reduce values of $M_{n}$. Maghnite- $\mathrm{H}^{+}$ proportions affect also the methacrylation yield of the resulted copolymer. As shown in Table 2, the methacrylation yield increases with Maghnite amount, confirming that Maghnite catalyzes also the methacrylation reaction of PLA-PEG-PLA copolymer. 
Di-methacrylated PLA-PEG-PLA by Maghnite $\mathrm{H}^{+}([$Lactide $] /[\mathrm{PEG}]$ in feed $=\mathbf{1 0}$, [Methacryloyl Chloride]/[PEG] in feed $=4, T=393 \mathrm{~K}$ )

\begin{tabular}{|c|c|c|c|c|}
\hline$M_{n}$ of PEG & Amount of catalyst, $\% \mathrm{w} / \mathrm{w}$ & Copolymerization yield, \% & Methacrylation yield $^{\mathrm{a}}, \%$ & $M_{n}$ of PLA block ${ }^{b}$ \\
\hline \multirow{6}{*}{1000} & 2 & 8 & 12 & 560 \\
\hline & 4 & 35 & 35 & 460 \\
\hline & 6 & 42 & 57 & 400 \\
\hline & 7 & 63 & 72 & 370 \\
\hline & 8 & 76 & 87 & 347 \\
\hline & 10 & 89 & 91 & 319 \\
\hline \multirow{6}{*}{2000} & 2 & 7 & 11 & 671 \\
\hline & 4 & 39 & 27 & 512 \\
\hline & 6 & 43 & 53 & 450 \\
\hline & 7 & 68 & 67 & 412 \\
\hline & 8 & 77 & 82 & 380 \\
\hline & 10 & 91 & 89 & 346 \\
\hline \multirow{6}{*}{3000} & 2 & 12 & 7 & 593 \\
\hline & 4 & 42 & 22 & 534 \\
\hline & 6 & 54 & 49 & 476 \\
\hline & 7 & 72 & 52 & 440 \\
\hline & 8 & 80 & 60 & 425 \\
\hline & 10 & 89 & 63 & 425 \\
\hline
\end{tabular}

Notes: ${ }^{a}$ Methacrylation yield was determined by comparing the integrations peak of vinyl protons $(6.1$ and $5.7 \mathrm{ppm})$ with non-methacrylated PLA chain ends at $4.3 \mathrm{ppm} ;{ }^{b}$ Estimated from the integrations of the peaks at 3.4 ppm $\left(I_{3,4}\right)$ (PLA block) and $4.8 \mathrm{ppm}\left(I_{4,8}\right)$ (PEG block) and average molecular weight of used PEG as described in the literature [24]

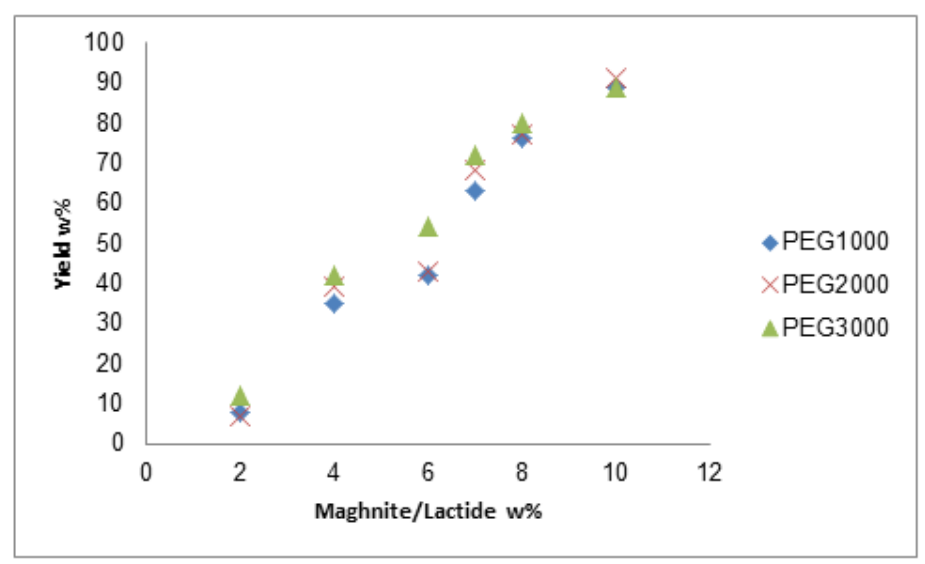

Fig. 4. Effect of Maghnite proportion on the copolymerization yield

\subsubsection{Effect of the PEG Mns on the reaction}

The effect of $M_{n}$ values on the yield of the reaction and on the PLA block length in the resulted copolymer was also studied. As shown in Figs. 4, 5 and Table 2, the nature of the used PEG in the reaction does not seem to affect the reaction, and the average molecular weights of PLA block and the yield of the reaction appears independent of the length of the used PEG.

These results are probably explained by the nature of the reaction conducted in bulk phase, in which the reactivity of the used PEG is not affected by their sizes.

The comparison of methacrylation yields (Table 2) obtained with PEG1000, PEG2000 and PEG3000, shows the decrease of the methacrylation yields with the copolymer chain length. This PEG reactivity inversely proportional to the length of polymer chains may be explained by the less accessible hydroxyl end groups of PLA-PEG-PLA copolymers for the reaction of methacrylation in longer polymer chains. 


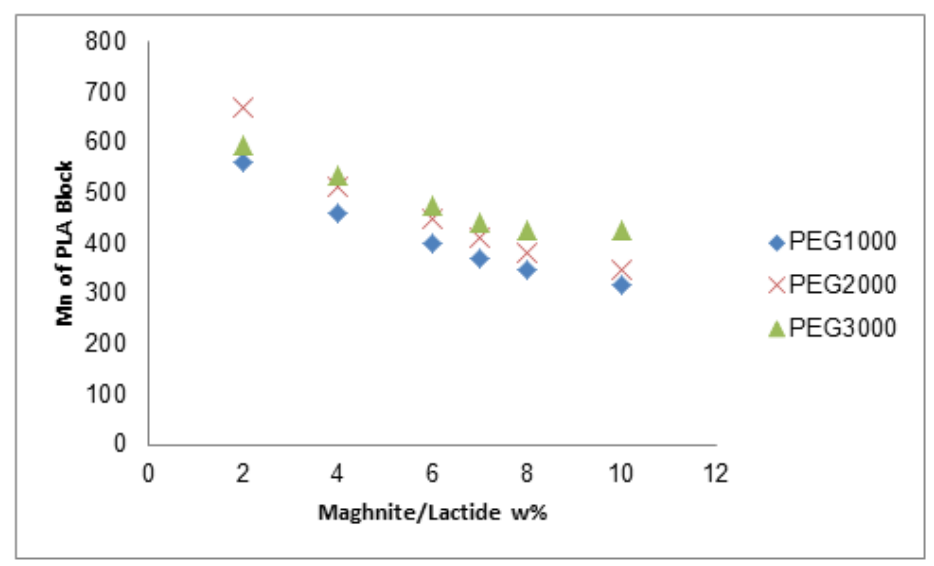

Fig. 5. Effect of Maghnite proportion on the length of PLA block

\section{Conclusions}

This paper reports on the use of Maghnite- $\mathrm{H}^{+}$as a non-toxic catalyst to produce di-methacrylatedpoly (lactide-block-ethylene glycol -block-lactide) functional copolymers. Due to the heterogenic aspect of the reaction, this simple and effective method provides a material totally free of catalyst traces observed with homogeneous classical catalysts, such as organometallic alcoxide. The structure of the resulted functional copolymer was analyzed by ${ }^{1} \mathrm{H}$ NMR and DSC. The effect of the amount of Maghnite- $\mathrm{H}^{+}$and the PEG length on the reaction was also investigated. The copolymerization and methacrylation yields increase with increasing Maghnite proportions. The average molecular weight of the PLA block decreases with Maghnite proportions. The methacrylation yield decreases with the length of the used PEG.

\section{References}

[1] Hsu Y., Masutani K., Yamaoka T., Kimura Y.:Polymer, 2015, 67, 157. https://doi.org/10.1016/j.polymer.2015.04.026

[2] Larrañeta E., Stewart S., Ervine M. et al.: J. Func. Biomat., 2018, 9, 113. https://doi.org/10.3390/jfb9010013

[3] Bhaskar B., Owen R.: J. Biomed Mater. Res., 2018, 106, 1334. https://doi.org/10.1002/jbm.a.36336

[4] Danafar H., Manjili H., Najafi M.: Drug. Res., 2016, 66, 495. https://doi.org/10.1055/s-0042-110931

[5] Danafar H., Rostamizadeh K., Hamidi M.: J. Pharm. Invest., 2018, 48, 381. https://doi.org/10.1007/s40005-017-0334-8

[6] Heidari K., Chan E., Young R. et al.: Ann. Biomed. Eng., 2017, 45, 1746. https://doi.org/10.1007/s10439-016-1749-5

[7] Sahoo S., Toh S., Goh J.: Biomaterials, 2010, 31, 2990. https://doi.org/10.1016/j.biomaterials.2010.01.004

[8] Luu Y., Kim K., Hsiao B. et al.: J. Control. Release, 2003, 89, 341. https://doi.org/10.1016/S0168-3659(03)00097-X
[9] Scaffaro R., Lopresti F., Botta L. et al.: J. Mech. Behav. Biomed. Mater., 2016, 54, 8.

[10] Venkatraman S., Jie P., Min F. et al.: Int. J. Pharm., 2005, 298, 219.

[11] Kaito T., Myoui A., Takaoka K. et al.: Biomaterials, 2005, 26, 73. https://doi.org/10.1016/j.biomaterials.2004.02.010

[12] Reena K., Balashanmugam P., Gajendiran M. et al.: J. Nanosci. Nanotech., 2016, 16, 4762. https://doi.org/10.1166/jnn.2016.12404

[13] Chitra A., Reena K., Manikandan K. et al.: J. Nanosci.

Nanotech., 2015, 15, 4984. https://doi.org/10.1166/jnn.2015.10023 [14] Ouyang P., Kang Y., Yin G. et al.: Front. Mater. Sci. China, 2009, 3, 15. https://doi.org/10.1007/s11706-009-0017-0

[15] Cosco D., Paolino D., Angelis F. et al.: Eur. J. Pharm.

Biopharm., 2015, 89, 30. https://doi.org/10.1016/j.ejpb.2014.11.012

[16] Yuan Z., Qu X., Wang Y. et al.: Colloid Surface B, 2015, 128, 489. https://doi.org/10.1016/j.colsurfb.2015.02.048

[17] Kim H., Kim E., Ha T. et al.: Colloid Surface B, 2015, 127,

206. https://doi.org/10.1016/j.colsurfb.2015.01.039

[18] Diao J., Wang H., Chang N. et al.:Dev. Biol., 2015, 406, 196. https://doi.org/10.1016/j.ydbio.2015.08.020

[19] Jain A., Goyal A., Mishra N. et al.:Int. J. Pharm., 2010, 387, 253. https://doi.org/10.1016/j.ijpharm.2009.12.013

[20] Jain A., Goyal A., Gupta N. et al.: J. Control. Release, 2009, 136, 161. https://doi.org/10.1016/j.jconrel.2009.02.010

[21] Nagahama K., Takahashi A., Ohya Y.: React. Funct. Polym., 2013, 73, 979 .

https://doi.org/10.1016/j.reactfunctpolym.2012.11.003

[22] Lim D.: J. Appl. Polym. Sci., 2000, 75, 1615.

https://doi.org/10.1002/(SICI) 1097-

4628(20000328)75:13<1615::AID-APP7>3.0.CO;2-L

[23] Matsumoto J., Nakada Y., Sakurai K. et al.: Int. J. Pharm., 1999, 185, 93. https://doi.org/10.1016/S0378-5173(99)00153-2

[24] Harrane A., Leroy A., Nouailhas H. et al.: Biomed. Mater., 2011, 6, 1. https://doi.org/10.1088/1748-6041/6/6/065006

[25] Kricheldorf H., Kreiser-Saunders I., Stricker

A.:Macromolecules, 2000, 33, 702.

https://doi.org/10.1021/ma991181w

[26] Arbaoui F., Boucherit M.: Appl. Clay. Sci., 2014, 91, 6. https://doi.org/10.1016/j.clay.2014.02.001 
[27] Bennabi S., Belbachir M.: Adv. Mater. Lett., 2015, 6, 271. https://doi.org/10.5185/amlett.2015.5660

[28] Akeb M., Harrane A., Belbachir M.: Green Mater., 2018, 6, 58. https://doi.org/10.1680/jgrma.17.00040

[29] Draoua Z., Harrane A., Belbachir M.: J. Macromol. Sci. A, 2015, 52, 130. https://doi.org/10.1080/10601325.2015.980763

[30] El-Kebir A., Harrane A., Belbachir M.: J. Sci. Eng., 2015, 41, 2179. https://doi.org/10.1007/s13369-015-1862-z

[31] Belbachir M., Bensaoula A.: Pat. US 7, 094, 823 B2, 2006.

[32] Ramazani F., Hiemstra C., Steendam R. et al.: Eur. J. Pharm. Biopharm. B., 2015, 95, 368.

https://doi.org/10.1016/j.ejpb.2015.02.011

[33] Yang J., Liang Y., Han C.: Polymer, 2015, 79, 56. https://doi.org/10.1016/j.polymer.2015.09.067

[34] Yang L., El Ghzaoui A., Li S.: Int. J. Pharm., 2010, 400, 96. https://doi.org/10.1016/j.ijpharm.2010.08.037

[35] Byun Y., Rodriguez K., Han J. et al.: Int. J. Biol. Macromol., 2015, 81, 591. https://doi.org/10.1016/j.ijbiomac.2015.08.036 [36] Elkebir A., Harrane A., Belbachir M.: Mater. Res., 2016, 19, 132. https://doi.org/10.1590/1980-5373-MR-2015-0322

\section{ПРЯМИЙ СИНТЕЗ І ХАРАКТЕРИСТИКА ФОТОЗШИТОГО БІОДЕГРАДАБЕЛЬНОГО ТРИБЛОК-КОПОЛІМЕРА РLA-PEG-PLA 3 МЕТАКРИЛАТНИМИ ФУНКЦИЙНИМИ ГРУПАМИ В ПРИСУТНОСТІ КАТАЛІЗАТОРА НА ОСНОВІ ЗЕЛЕНОЇ МОНТМОРИЛОНІТОВОЇ ГЛИНИ}

Анотація. Диметакриловані триблок-кополімери PLAPEG-PLA полілактиду (PLA) $i$ поліетиленгліколю (PEG) синтезовані внаслідок одностадійної катіонної полімеризації в масі лактиду в присутності PEG з різними молекулярними масами. Maghnite- $H^{+}$, кислотна монтмориллонитова глина, використана як твердий нетоксичний каталізатор. 3 а допомогою ${ }^{I}$ Н ЯМР $і$ ДСК проведено аналіз одержаного диметакрилатного сополімеру. Досліджено вилив кількості Maghnite- $H^{+}$та середньої молекулярної маси PEG на виходи кополімеризаиї та метакрилування, а також на середню молекулярну масу отриманих кополімерів.

Ключові слова: розкриття кільия, полімеризація, блоккополімери, катіонна полімеризація, метакрилатні кополімери, монтморилоніт. 